\title{
ANALYSIS OF THE POSSIBILITIES OF TEACHING ELECTRICAL ENGINEERING AT THE BASIC SCHOOL
}

\author{
Čestmír SERAFÍ $N^{*}$, Univerzita Palackého v Olomouci
}

Přijato: 15. 11. 2015 / Akceptováno: 5. 1.2016

Typ článku: Teoretická studie

DOI: $10.5507 /$ jtie.2016.001

Abstract: The post notes the analysis of the possibilities of education in electrical engineering or electronics in the elementary school. In the paper is analysed the current status of curricular documents applicable to the education system in the Czech republic and following the technical preparation of students for the choice of his profession. Particular emphasis is placed upon the necessity and the need for technical knowledge and skills for the normal life of man in society.

Key words: education; curriculum; technical education; the framework educational program; the person and the world of work; electrical engineering.

\section{ANALÝZA MOŽNOSTÍ VÝUKY ELEKTROTECHNIKY NA ZÁKLADNÍ ŠKOLE}

Resumé: Příspěvek uvádi analýzu možností vzdělávání v elektrotechnice resp. elektronice na základní škole. V př́spěvku je analyzován současný stav kurikulárních dokumenti̊ platných pro systém vzdèláváni v České republice a návaznosti na technickou prípravu žáků pro volbu svého povolání. Zvláště je zdůrazňována nutnost a potřebnost technických znalostí a dovednosti pro běžný život člověka ve společnosti.

Klíčová slova: vzdělávání; kurikulum; technická výchova; rámcový vzdělávací program; člověk a svět práce; elektrotechnika.

\section{ERIHPLUS}

*Autor pro korespondenci: cestmir.serafin@upol.cz
This journal was approved on 2015-04-23 according to ERIH PLUS criteria for inclusion. 


\section{1 Úvod}

Technická zařízení, spotřebiče, zvláště ve spojení s elektř̌nou jsou běžnou součástí našeho života a tvoří nedílnou životní sféru obecně nazývanou technosférou (Stoffa, 1997). Technika se dnes rozvíjí nevídaným tempem, radikálně tak ovlivňuje způsob našeho života.

Analyzujeme-li možnosti vzdělávání v/o elektrotechnice resp. elektronice na základní škole, je nutné vnímat elektrotechniku a elektroniku v určitém kontextu, který je v současné podobě Rámcových vzdělávacích programů pro základní vzdělávání (RVP, 2013) reálný ve výukovém procesu základní školy. Zároveň je však třeba chápat elektrotechniku a elektroniku na tomto stupni vzdělávání jako součást obecného pojetí techniky, které by mělo být standardem v př́ípravě člověka na život.

Je známo, že řecké slovo „techné“ udává schopnost umět něco udělat, znamená to nejen stroje, př́istroje a zařízení, ale také postup k dosažení nějakého cíle. Každá lidská činnost vyžaduje technické vybavení nebo technický postup, nebo obojí. Tento obecně známý princip je běžně vnímán jako naprostá samozřejmost, přesto nebo snad i právě proto je často brán jako samozřejmý i z pohledu psychologického, z pohledu našeho běžného vnímání a proživání, nebot' jak jinak si lze vysvětlit, že vzdělávání budoucích generací již desítky let postrádá některé základní poznatky o technice a že tvůrci kurikulárních dokumentů při jejich tvorbě kladli větší důraz na jiné oblasti tzv. „měkké kompetence“ (což je i patrné z níže uvedené analýzy). Výsledkem pak je i často mediálně proklamovaná skutečnost, že $\mathrm{v}$ dnešní době děti ztrácí manuální zručnost a mají nedostatečné technické a $\mathrm{v}$ běžném životě prakticky využitelné elementární technické vědomosti a dovednosti (jejíž součástí jsou i vědomosti a dovednosti z oblasti elektrotechniky), které by měly být nedílnou součástí základního všeobecného vzdělávání (Lukáčová, 2014): „Česká republika bude v horizontu 25 let čelit katastrofálnimu nedostatku špičkových odborníkủ. Na trhu práce již nyní citelně chybí lidé s technickým vzděláním od učňovských oborů po vysokoškolské. Shodly se na tom oslovené personálni agentury. Celosvětově jsou podle nich na prvních přičkách nedostatkových profesí řemeslníci“ ${ }^{1}$. „Na trhu práce je fatální nedostatek mladých techniků a řemeslníků. Strojírenství, elektroenergetice a dalším podobně technicky zaměřným odvětvím, hrozí již zcela reálně v souvislosti s přirozenou generačni obměnou zaměstnanci̊ personálni krize“ 2 .

\section{Použité metody}

Analyzovaný problém realizace výuky o elektrotechnice a elektronice na základním stupni školy je veden $\mathrm{v}$ podobě teoretické studie zabývající možností výuky o elektřině mimo předmět fyzika, který je zaměřen nikoliv tak na praktické konsekvence elektrotechniky a elektroniky $\mathrm{v}$ běžném životě, jako na principiální vymezení teoretických základů tohoto oboru. Naše studie je postavena na analyticko-syntetickém

${ }^{1}$ Denik.cz [online]. 31. 1. 2015 [cit. 2015-02-01]. Dostupné z: http://www.denik.cz/ekonomika/ceskobude-celit-silnemu-nedostatku-odborniku-shoduji-se-personalni-agentury-201.html

${ }^{2}$ Novinky.cz [online]. 6. 10. 2014 [cit. 2015-08-01]. Dostupné z: http://www.novinky.cz/vasezpravy/jihocesky-kraj/ceske-budejovice/3112-27457-mladi-technici-a-remeslnici-jsou-poklademtrhu-prace.html 
př́istupu shrnujícím dosavadní poznatky, analyzující je na základě komparací a jejich systematizaci je následně využít $\mathrm{k}$ vyvození $\mathrm{v}$ obecně platných závěrech. Základ tedy tvoří metody analýzy kurikulárních dokumentů a komparativní metody $\mathrm{v}$ práci $\mathrm{s}$ dokumenty vztahujícími se $\mathrm{k}$ analyzovanému problému.

\section{Kurikulární dokumenty v České republice}

Současný systém kurikulárních dokumentů je rozdělen na část státní a část školní. Na úrovni státní mluvíme o Národním programu rozvoje vzdělávání v České Republice (tzv. Bílá kniha), která byla podrobena v rámci Strategie 2020 poměrně ostré kritice $\mathrm{v}$ roce 2009 . Výsledkem této analýzy bylo, že mnohé oblasti nebyly naplněny, nebo ve svém výsledku vyzněly jinak, než bylo zamýšleno: „Napřiklad kurikulární reforma byla realizována bez zastřešujicího Státního programu vzděláváni pro dèti a mládež od 3 do 19 let, což mělo pravděpodobně závažné důsledky pro přijetí reformy odbornou $i$ širokou veřejností $i$ pro podobu rámcových vzdělávacich programú pro jednotlivé stupně vzdělávání. Dílčí kroky v oblasti evaluace byly realizovány bez vytvoření systému, který by zajistil vzájemnou provázanost jednotlivých evaluačních počinu $i$ jejich návaznost na cile vzdělávací politiky“. „Nadprodukce nekvalitních "strategických“ dokumentů je dle našeho názoru jen vrcholem ledovce operativního a nesystematického prístupu k otázkám vzdèláváni a jeho reformy. Ten zahrnuje zejména nedostatečné znalosti v oblasti tvorby vzdělávaci politiky, vzdělávaci politiku založenou nikoli na dostupných poznatcich (evidence - based policy), ale na názorech, a s tím souvisejicí nefunkčni institucionální uspořádání správy ve školství. Dle našeho názoru vzdělávaci politika v České republice nepotřebuje dalši „,jednorázové “ dokumenty typu Bílé knihy, ale spiše nastolení kontinuálního procesu strategického ř́zeni"

$\mathrm{Na}$ základě výše uvedeného strategického dokumentu byly $\mathrm{v}$ minulých létech realizovány reformní kroky v podobě tzv. rámcových vzdělávacích programů, které jsou v současnosti platné pro předškolní, základní, gymnaziální, stř̌ední odborné a jiné vzdělávání - tedy vlastně pro všechny úrovně mimo terciálního vzdělávání. Podmínkou vymezenou i v rámci zákonných opatření je pak následná realizace tzv. školní úrovně tvořené školními vzdělávacími programy, které si jednotlivé vzdělávací instituce vytvářejí samostatně na základě jim daného rámcového vzdělávacího programu.

$\mathrm{V}$ príípadě základních škol se jedná o Rámcový vzdělávací program pro základní vzdělávání (RVP, 2013). Tento dokument stanovuje vymezení o zaměření, obsahu a výsledcích základního (primárního a nižšího sekundárního) vzdělávání na úrovni státu, tedy vymezuje:

1. základní směry povinného vzdělávání - obecné cíle vzdělávání:

a) strategie učení a motivace pro celoživotní učení;

b) základy tvořivého myšlení, logického uvažování a řešení problémů;

c) základy všestranné komunikace,

d) spolupráce a respektování práce a úspěchu ostatních;

e) utváření a vhodné projevy svobodné a zodpovědné osobnosti;

f) rozvoj a projevování pozitivních citů v jednání a prožívání;

g) pozitivní vztah ke zdraví;

h) schopnost žít s ostatními;

i) poznání a uplatňování svých reálných možností; 
2. skupiny klíčových kompetencí, do kterých se promítají výsledky vzdělávání:
a) učení;
b) řešení problémů;
c) komunikace;
d) pracovní činnosti a spolupráce.

Rámcový vzdělávací program pro základní vzdělávání (RVP, 2013) definuje několik vzdělávacích oblastí a v nich zakotvené vzdělávací obory jako primární obsah výuky na základních školách (viz tabulka 1). Kromě tohoto jsou stanovena tzv. průřezová témata, které reflektují aktuální problémy současného světa a propojují vzdělávací obsahy oborů, čímž mají přispívat ke komplexnosti vzdělávání žáků:

1. výchova demokratického občana;

2. osobnostní a sociální výchova;

3. výchova $\mathrm{k}$ myšlení v evropských a globálních souvislostech;

4. environmentální výchova;

5. mediální výchova;

6. multikulturní výchova.

Tabulka 1 Přehled vzdělávacích oblastí včetně jim pridružených vzdělávacích obori̊

\begin{tabular}{|c|c|}
\hline Vzdělávací oblast & Vzdělávací obor \\
\hline Jazyk a jazyková komunikace & Český jazyk a literatura \\
\hline Matematika a její aplikace & Matematika a její aplikace \\
\hline Informační a komunikační technologie & Informační a komunikační technologie \\
\hline Člověk a jeho svět & Člověk a jeho svět \\
\hline Člověk a společnost & Dějepis, Výchova k občanství \\
\hline Člověk a př́roda & Fyzika, Chemie, Př́rodopis, Zeměpis \\
\hline Umění a kultura & Hudební výchova, Výtvarná výchova \\
\hline Člověk a zdraví & Výchova ke zdraví, Tělesná výchova \\
\hline Člověk a svět práce & Člověk a svět práce \\
\hline
\end{tabular}

Jednou ze vzdělávacích oblastí a potažmo oborů je "Člověk a svět práce“, která se má primárně zaměřit na pracovní činnosti a technologie směrem $\mathrm{k}$ uživatelským dovednostem $\mathrm{v}$ různých oborech lidské činnosti, včetně vytváření životní a profesní orientace žáků. Koncepce má vycházet z konkrétních životních situací, s nimiž žáci mohou přicházet do kontaktu. Vzdělávání tak má rozvíjet klíčové kompetence žáků $\mathrm{k}(\mathrm{RVP}, 2013)$ :

- pozitivnímu vztahu k práci a k odpovědnosti za kvalitu svých i společných výsledků práce;

- osvojení základních pracovních dovedností a návyků z různých pracovních oblastí, $\mathrm{k}$ organizaci a plánování práce a $\mathrm{k}$ používání vhodných nástrojů, nářadí a pomůcek při práci i v běžném životě;

- vytrvalosti a soustavnosti při plnění zadaných úkolů, k uplatňování tvořivosti a vlastních nápadů při pracovní činnosti a k vynakládání úsilí na dosažení kvalitního výsledku;

- poznání, že technika jako významná součást lidské kultury je vždy úzce spojena s pracovní činností člověka; 
- autentickému a objektivnímu poznávání okolního světa, $\mathrm{k}$ potřebné sebedůvěře, $\mathrm{k}$ novému postoji a hodnotám ve vztahu $\mathrm{k}$ práci člověka, technice a životnímu prostředí;

- chápání práce a pracovní činnosti jako př́ležitosti k seberealizaci, sebeaktualizaci a k rozvíjení podnikatelského myšlení;

- orientaci v různých oborech lidské činnosti, formách fyzické a duševní práce a osvojení potřebných poznatků a dovedností významných pro možnost uplatnění, pro volbu vlastního profesního zaměření a pro další životní a profesní orientaci.

Vzdělávací obsah je rozdělen na 1 . stupni na čtyři tematické okruhy s minimální časovou dotací 5 hodin (RVP, 2013):

1. Práce s drobným materiálem.

2. Konstrukční činnosti.

3. Pěstitelské práce.

4. Př́íprava pokrmů.

$\mathrm{Na}$ 2. stupni je vzdělávací obsah rozdělen na osm tematických okruhů, které tvoř́i pouze nabídku s minimální časovou dotací pouhých 3 hodin. Pouze tematický okruh Svět práce je povinný (RVP, 2013):

1. Práce s technickými materiály.

2. Design a konstruování.

3. Pěstitelské práce a chovatelství.

4. Provoz a údržba domácnosti.

5. Př́íprava pokrmů.

6. Práce s laboratorní technikou.

7. Využití digitálních technologií

8. Svět práce.

V oboru Člověk a svět práce, ve kterém se mají žáci učit pracovat s různými materiály a osvojovat si základní pracovní dovednosti a návyky, se tak mohou této činnosti věnovat vlastně jen minimálně a při minimální časové dotaci, nebot' školy $\mathrm{v}$ rámci svých školních vzdělávacích programů mají pouze minimum možností jak toto naplnit. V mnoha př́padech jim v posledních létech zůstává jedině projekční činnost v rámci Operačního programu Vzdělávání pro konkurenceschopnost ${ }^{3}$, kde se těmto aktivitám mohou alespoň částečně věnovat nad rámec vzdělávacích programů.

V porovnání s jinými vzdělávacími oblastmi časová nedostatečnost vzdělávací oblasti Člověk a svět práce zvlášt' vynikne - viz tabulka 2.

Tabulka 2 Minimální časová dotace dle RVP (RVP, 2013)

\begin{tabular}{|c|c|c|}
\hline Vzdělávací oblasti & 1. stupeň & 2. stupeň \\
\hline Člověk a jeho svět & 12 & - \\
\hline Člověk a společnost & - & 11 \\
\hline Umění a kultura & 12 & 10 \\
\hline Člověk a zdraví & 10 & 10 \\
\hline Člověk a svět práce & $\mathbf{5}$ & $\mathbf{3}$ \\
\hline
\end{tabular}

${ }^{3}$ http://www.op-vk.cz/ 


\section{4 Člověk a svět práce a elektrotechnika}

Chceme-li mluvit o elektrotechnice, resp. elektronice v kontextu základního vzdělávání, pak nás pochopitelně bude zajímat vzdělávací oblast (předmět) Člověk a svět práce. Kromě této oblasti lze však náplň oboru elektrotechnika nalézt i ve vzdělávací oblasti Člověk a př́roda, vzdělávací obor Fyzika.

V předmětu Člověk a svět práce do obsahu elektrotechniky bezpodmínečně zasahují tyto tematické celky:

- Design a konstruování - zaměření je na práce s různými typy stavebnic a také na uvedení do problematiky technického kreslení a konstruování.

- Provoz a údržba domácnosti - cílem je představit žákům podmínky správného fungování domácnosti jak po stránce údržby, tak i jejího finančního zabezpečení.

- Práce s laboratorní technikou - je o využití různých měříích př́istrojů při různých formách lidské činnosti. Taktéž si klade za cíl naučit žáky zápisům a formulacím z provedených pokusů.

Vycházíme-li z toho, že základní vzdělávání buduje systém gramotností, mezi něž patř́ i tzv. technická gramotnost, pak ve vztahu k elektrotechnice je úkolem základní školy seznámit žáky s touto oblastí, s principy a zákony o něǰ se opírá, se způsoby bezpečného užívání a s obsluhou běžně se vyskytujících domácích elektrických spotřebičů. Tento cíl byl dán před platností Rámcových vzdělávacích programů, tedy před rokem 2004 ve výuce předmětu Praktické činnosti realizací celku Elektrotechnika kolem nás (Janda, 2009). V této části výuky bývali žáci názorně seznamováni s vybranými elektrotechnickými jevy, principy a elektrickými př́stroji, kdy při uvědomělém uplatnění získaných znalostí jim byla zprostředkována i ochrana před úrazem elektrickým proudem $\mathrm{v}$ běžném životě a součástí byla i př́iprava části žáků na výkon budoucího povolání elektrotechnického charakteru po absolvování př́slušného středoškolského nebo vysokoškolského vzdělávání.

$\mathrm{V}$ posledních letech zejména díky Operačním programům ${ }^{4},{ }^{5}$ a podpoře ze strany Evropské unie se alespoň částečně nepř́znivá situace $\mathrm{v}$ této oblasti poněkud změnila, kdy na všech vzdělávacích úrovních byly v letech 2007 - 2013 realizovány projekty, které si kladly za cíl posílit tuto opomíjenou stránku. Jako některé př́klady z mnoha desítek projektů je možno uvést:

- „Technikou do nitra člověka“6 - projekt zaměřen posílení úrovně polytechnického vzdělávání učitelek mateřských škol.

- „Technické mateřské školy"7 - projekt pro učitelky mateřských škol věnující pozornost polytechnické výchově již v raném věku.

- „Dílna techniky ve světě dètí - zážitkové tvưrči dílny v rozvoji technického myšlení učitelů a dětí v mateřské škole“8 - projekt zabývající se efektivním přenosem poznatků z oblasti polytechnického vzdělávání, vedoucích k prohloubení zájmu o technické obory.

\footnotetext{
${ }^{4}$ http://www.op-vk.cz/

${ }^{5} \mathrm{http}: / /$ www.opvavpi.cz/

${ }^{6} \mathrm{http}: / /$ esf.fbmi.cvut.cz/0099

${ }^{7} \mathrm{http}: / /$ www.technicke-ms.cz/

${ }^{8}$ http://www.osu.cz/index.php?kategorie=915\&id=12175
} 
- „Okna technickým oborům dokořán“9 - jehož cílem bylo zlepšení podmínek pro výuku technických a řemeslných oborů, včetně vytvoření podmínek pro zvýšenou motivaci žáků základních škol ke vzdělávání $\mathrm{v}$ těchto oborech za účelem jejich většího uplatnění na trhu práce v průmyslu.

- „Pevnost poznáni Olomouc“10 - která je prvním interaktivním muzeem popularizace vědy na střední Moravě. Sídlí v areálu Korunní pevnůstky v centru Olomouce a patř́ do kategorie tzv. science center, poskytujících neformální prostředí pro hravé objevování prírodních a společenských jevů.

- „Svět techniky"11 - cíle se zaměřují na změnu image technických oborů a získání nových talentů. Svět techniky má být místem pro neformální technické a př́rodovědné vzdělávání, pro popularizaci vědy a netradiční výuku.

Dle analýz Národního ústavu pro vzdělávání (NÚV, 2004-2012) vyplývá, že podniky $\mathrm{v}$ rámci tzv. sekundárního sektoru, tedy z oblasti průmyslu, mají dlouhodobě problém najít kvalifikované pracovníky.

Podle bývalého ministra školství Marcela Chládka ${ }^{12}:$ „Musí skončit pohled na učňovské školství, že to je o špinavých montérkách. Musíme napravit celospolečenský pohled na celou tuto oblast. Proto jsme se na dnešni schüzce rozhodli označit rok 2015 rokem technického vzdèlávání. Proběhnou dny otevřených dveři ve všech školách a podnicich, které se do tohoto projektu zapojí, aby všichni viděli, co tato oblast obnášì.“"

Ministerstvo školství, mládeže a tělovýchovy České republiky si určilo tři hlavní priority zvýšení efektivity př́ípravy budoucích techniků:

1. Podpora oborů podle potřeb trhu práce, tedy i na základě predikcí určit, které obory stojí za to podpořit.

2. Úprava financování odborného školství, kdy by např́íklad zaměstnavatelé mohli uplatnit daňové úlevy za stipendia studentům.

3. Zlepšení kvality odborného školství, tedy realizace praktické výuky v prostředí reálné praxe.

Bývalý ministr školství Marcel Chládek v této souvislosti uvedl: „Musíme začit ne u učňovského školství, ale už u předškolního vzdèlávání. Vybizím tedy podniky. Podpořme projekty ve školách na základě stavebnic typu Merkur, pojd’me vybavit dílny...."

\section{Výsledky a diskuse}

V kontextu zde uváděných faktů, lze vyvozovat opomíjenost výuky o technice a zvláště pak o elektrotechnice na základních školách kde např́íklad téma Práce s laboratorní technikou, se na základních školách se vyučuje minimálně a v pojetí, které je nedostatečné pro dané cíle (Havelka, 2013).

\footnotetext{
${ }^{9}$ http://www.khkvysocina.cz/?clanek=270

${ }^{10} \mathrm{http}: / /$ www.pevnostpoznani.cz/

${ }^{11} \mathrm{http}: / /$ www.svet-techniky-ostrava.cz/

${ }^{12} \mathrm{http}: / /$ www.msmt.cz/ministerstvo/novinar/marcel-chladek-2015-bude-rokem-technickehovzdelavani
} 
Lze souhlasit, že tato okolnost je dána i nutností mít $\mathrm{k}$ dispozici určité minimální vybavení (např. v podobě elektrotechnických stavebnic, měřicích př́strojů, apod.) problémem daný nevyhovujícími podmínkami na základních školách, které díky reformním snahám minulých let vlastně zlikvidovaly laboratoře a dílny vybudované v osmdesátých létech minulého století, i když v dnešním pojetí by byly zastaralé a bezpečnostně nevyhovující - daly by se však za mnohem menší náklady rekonstruovat, než nyní nově vybudovat.

Podíváme-li se na nyní platné kutikulární dokumenty, pak i v nich však přes jejich omezení lze najít styčná místa pro oblasti výuky o elektrotechnice na úrovni základní školy. Základní teoretické zakotvení elektrotechniky v okruhu Člověk a př́roda v předmětu Fyzika, kde lze nalézt potřebné výstupy v kapitole Elektromagnetické a světelné děje (dle Rámcového vzdělávacího programu pro základní vzdělávání):

- Žák sestaví správně podle schématu elektrický obvod a analyzuje správně schéma reálného obvodu.

- Žák rozliší stejnosměrný proud od střídavého a změří elektrický proud a napětí.

- Žák rozliší vodič, izolant a polovodič na základě analýzy jejich vlastností

- Žák využívá Ohmův zákon pro část obvodu při řešení praktických problémů.

- Žák využívá prakticky poznatky o působení magnetického pole na magnet a cívku s proudem a o vlivu změny magnetického pole $\mathrm{v}$ okolí cívky na vnik indukovaného napětí v ní.

- Žák zapojí správně polovodičovou diodu.

- Žák využivá zákona o přímočarém šíření světla ve stejnorodém optickém prostředí a zákona odrazu světla při řešení problémů a úloh.

- Žák rozhodne ze znalosti rychlosti světla ve dvou různých prostředích, zda se světlo bude lámat ke kolmici či od kolmice, a využívá této zkušenosti při analýze průchodu světla čočkami.

Je nutné zde ovšem zdůraznit, že $\mathrm{v}$ předmětu Fyzika je elektrotechnika pojata fyzikálně a právě v pojetí technických předmětů se tyto znalosti a následně dovednosti vždy prohlubovaly směrem ke konkrétním aplikacím, př́strojům, strojům i technickým postupům. V Rámcovém vzdělávacím programu tak nyní přejímá tuto funkci tematický okruh Práce s laboratorní technikou - očekávané výstupy (dle Rámcového vzdělávacího programu pro základní vzdělávání):

- Žák vybere a prakticky využívá vhodné pracovní postupy, přístroje, zařízení a pomůcky pro konání konkrétních pozorování, měření a experimentů.

- Žák zpracuje protokol o cíli, průběhu a výsledcích své experimentální práce a zformuluje $\mathrm{v}$ něm závěry, $\mathrm{k}$ nimž dospěl.

- Žák vyhledá $\mathrm{v}$ dostupných informačních zdrojích všechny podklady, jež mu co nejlépe pomohou provést danou experimentální práci.

- Žák dodržuje pravidla bezpečné práce a ochrany životního prostředí při experimentální práci.

- Žák poskytne první pomoc při úrazu v laboratoři.

Z výše uvedeného je patrné, že v určité omezené míře lze v současných kurikulárních podmínkách realizovat výuku o elektrotechnice, resp. elektronice na základní škole, ale pro tuto oblast jsou nutné určité minimální podmínky: 
1. Zařazení výuky o elektrotechnice do vzdělávací oblasti Člověk a svět práce na úrovni Školního vzdělávacího programu.

2. Materiální vybavení v podobě minimálně elektrotechnických a elektronických stavebnic, základních měřicích přístrojů a pomůcek.

3. Učitel znalý dané problematiky, schopný didakticky předat základní znalosti a dovednosti svým žákům.

Za velmi důležité lze pokládat kromě lidských a materiálních zdrojů i spojení teorie a praxe, kdy výuka teorie se stává pro žáky zajímavou jedině praktickou činností. Jedním $\mathrm{z}$ názorných prostředků přispívajících především $\mathrm{k}$ vytváření a podpoře rozvoje technické gramotnosti, myšlení a uživatelských dovedností jsou elektrotechnické stavebnice. Propojením teorie a praxe sehrávají svou úlohu rovněž i v oblasti profesní orientace př̀i volbě některého $\mathrm{z}$ elektrotechnických povolání. Jde především o povzbuzení zájmů o techniku, podpora aktivního učení činností a vnášení herních prvků do procesu výuky.

Z pohledu historie využívání elektrotechnických stavebnic na českých školách má dlouhodobou tradici a s ohledem na jejich nesporný didakticky pozitivní efekt na výuku si využívání elektrotechnických stavebnic nachází i svou další budoucnost. Jen málokterý učitel si v dnešní době dokáže představit výuku bez učebních pomůcek, čímž samozřejmě jsou i elektrotechnické stavebnice (Dostál, 2008).

Aplikací učebních pomůcek je možno využívat efektivnějších výukových metod a je možno tak lépe a efektivněji dosahovat učitelem vytyčených a žáky akceptovaných cílů. Badatelsky aktivizující př́stup umožňuje bezprostřední a cílevědomé zkoumání jevi̊ a objektů - umožňuje experimentování. Takto je tomu právě při využití elektrotechnických stavebnic ve výuce (Dostál, 2015).

Využívání elektrotechnických stavebnic, jak zde již bylo uvedeno, má své opodstatnění a v závislosti na způsobu použití mohou plnit ve výuce mnoho funkcí:

- pedagogické, kterými přispívají k názornosti a konkretizují představy a pojmy, zvyšují aktivitu žáků na práci s technikou, rozvíjejí aktivní vnímání, zvyšují pozornost, rozvíjejí představivost, usnadňují zapamatování, rozvíjejí technické myšlení, technickou tvořivost, přispívají k individualizaci výuky, napomáhají rozhodování při volbě povolání atd.;

- psychologické, jež aktivizují žáka, motivují ho povzbuzením zájmu o techniku, umožňují zpětnou vazbu, individuální tempo učení jednotlivých žáků a podporují herní prvky ve výuce;

- hygienické, aktivizací žáka snižují únavu a zvyšují pozornost žáků;

- ekonomické - zvyšují efektivnost výuky.

\section{Závěr}

Tempo vědeckotechnického rozvoje a rychlost ve výzkumu, výrobě a uvádění nových elektrotechnických zařízení na trh se pochopitelně má odrážet také ve školní praxi. Nároky na odbornou teoretickou i praktickou př́ípravu žáků i na další vzdělávání učitelů se neustále zvyšují. Praxe totiž vyžaduje absolventy se schopností technického myšlení, s vysokým stupněm technické kreativity a také se schopností pracovat samostatně a nést odpovědnost za výsledky své práce.

Změna kurikulárních dokumentů jak na úrovni státu, tak na úrovni školy je jen jedním z možných předpokladů potřebných změn bez kterých ale proklamace 
o nedostatku techniků a kroků tím směrem realizovaných, zůstane nadále na úrovni proklamací. Pokud však započne skutečná změna $\mathrm{v}$ této oblasti, pak jedním z prostředků pro zvládnutí elektrotechniky ve výchovně-vzdělávacím procesu jsou právě elektrotechnické stavebnice. Důvodů vedoucích $\mathrm{k}$ jejich zařazení do hodin teoretické i praktické př́ípravy je více, ale určující je naplnění principu názornosti, na nichž je již jejich konstrukce založena, dále schopnost rozvíjet u žáků kreativitu, schopnost přemýšlet, pracovat samostatně a rozhodovat se při řešení zadaných úkolů. Důležitou okolností je i možnost osvojování si při práci se stavebnicemi nezbytných pracovních návyků a i pravidel bezpečnosti práce. Pro učitele mohou elektrotechnické stavebnice být jedním z možných nástrojů motivace žáků, jak vnést do výuky prvky hravosti a při tom zajímavou i přitažlivou formou teoretické poznatky nejen vysvětlit, procvičit ale i jednoduše zkontrolovat její zvládání.

Je tedy pochopitelné, že zařazení elektrotechnických stavebnic jakožto vysoce moderního a přitom intuitivního didaktického prostředku do výuky vede $\mathrm{k}$ vy̌šší motivaci žáků, $\mathrm{k}$ rozvíjení jejich tvořivosti a samostatnosti při řešení zadaných úkolů a tím celkově k vyšší efektivitě výuky.

\section{Literatura}

Analýza naplněni cílu Národního programu rozvoje vzdělávání v České republice (Bílé knihy) v oblasti predškolního, základního a středního vzdělávání. (2009). [online]. [cit. 2015-10-10].

Dostupné z: http://www.vzdelavani2020.cz/images_obsah/dokumenty/knihovnakoncepci /bila-kniha/av_evaluace_bk.pdf.

Dostál, J. (2008). Elektrotechnické stavebnice (teorie a výsledky výzkumu). Olomouc: Votobia.

Dostál, J. (2015). Inquiry-based instruction: concept, essence, importance and contribution. Olomouc: Univerzita Palackého v Olomouci.

Havelka, M. (2010). Dílčí posouzení stavu realizace výuky vzdělávací oblasti Člověk a svět práce na základních školách na základě analýzy školních vzdělávacích programů. Journal of Technology and Information Education, č. 2/2010, vol. 2, s. 33-39.

Janda, O. (2009) Absence techniky a technické výchovy v učebních plánech pro základní vzdělávání. In Trendy ve vzdělávání 2009. Olomouc: VOTOBIA Olomouc, s. 77 - 83.

Lukáčová. D. (2014) Technické vzdelávanie - súčast' všeobecného vzdelávania na slovensku. Jurnal of Technology and Information Education 2/2014, Vol. 6, $8 \mathrm{~s}$.

RVP (2013) Rámcový vzdělávací program pro základni vzdélávání [online]. MŠMT [cit. 2015-10-10]. Dostupné z: http://www.msmt.cz/vzdelavani/skolstvi-vcr/skolskareforma/ramcove-vzdelavaci-programy.

Stoffa, J. (1997). Pojem technosféra $\mathrm{v}$ terminologickom systéme vedného odboru technická výchova. In Technické vzdelávanie ako súcast' všeobecného vzdelania. Banská Bystrica: Univerzita Mateja Bela, s. 200 - 203.

NúV (2004-2012) Vazby vzdělávání a trhu práce. Obsahová analýza závěrečných zpráv $z$ výběrových šetřeni realizovaných v obdobi 2004 - 2012 [online]. NúV [cit. 2015-11-

11]. Dostupné z:

http://www.nuv.cz/uploads/POSPOLU/Studie_vyberova_setreni_NUV_FIN.pdf 